\title{
Irena Bajerowa, \\ Zarys historii języka polskiego 1939-2000, \\ PWN, Warszawa 2003, s. 165
}

Niełatwo znaleźć wśród polskich historyków języka osobę bardziej uprawnioną do napisania ostatniego z możliwych fragmentu dziejów polszczyzny, czyli okresu obejmującego drugą połowę XX wieku, niż Irenę Bajerową. Przemawia za tym nie tylko znakomita pozycja naukowa autorki, ugruntowana cennymi monografiami ale też swoiste dziedzictwo. Irena Bajerowa, $\mathrm{z}$ domu Klemensiewiczówna, jest $\mathrm{w}$ istocie autorką trzeciego tomu monumentalnego, wielokrotnie wznawianego i do dziś wykorzystywanego podręcznika Historia języka polskiego, który zawdzięczamy przedwcześnie zmarłemu Zenonowi Klemesiewiczowi.

Omawiana pozycja nie jest zresztą pierwszą podjętą przez I. Bajerową próbą zmagania się z materią syntezy. Spod jej ręki wyszło już monograficzne opracowanie polszczyzny wieku XVIII i obszerne, bo liczące trzy części, syntetyczne ujęcie polszczyzny ogólnej okresu zaborów.

Ze wstępu, w którym została przedstawiona koncepcja podręcznika, dowiadujemy się, że Zarys został pomyślany i zrealizowany jako uzupełnienie i swoista kontynuacja dzieła Klemensiewicza. Autorka jednoznacznie mówi, że przejmuje za Historiq metodę, kompozycję i dobór tematów, ale podkreśla zarazem, że pewne elementy Zarysu stanowią novum (s. 7-10).

Recenzenci dzieła Klemensiewicza zgodnie uznali je za pierwszą udaną próbę połączenia wewnętrznego i zewnętrznego oglądu dziejów języka polskiego. To ujęcie kontynuuje w swej pracy Bajerowa, z tym że jeszcze wyraźniej niż sam Klemensiewicz, mianowicie przez odpowiednie tytułowanie części składowych, podkreśla współwystępowanie dwu wyróżnianych przez historyków języka punktów widzenia. Trójdzielna kompozycja całej pracy jest dokładnym odwzorowaniem 
układu, jaki przyjął w swej Historii Klemensiewicz. Dla porównania $\mathrm{w}$ tomie trzecim, który obejmuje dobę nowopolską, mamy, choć może wyróżniane mniej wyraziście jak w Zarysie: uwarunkowania społeczno-polityczne, kulturalno-oświatowe rozwoju języka polskiego doby nowopolskiej i jako bardzo istotny czynnik sprawczy - piśmiennictwo, następnie charakterystykę nowopolskiego systemu gramatycznego i słownikowego, wreszcie omówienie ortografii i ortofonii oraz podręczników i gramatyk epoki. Zarys, poza kilkunastostronicowym wprowadzeniem, zawiera natomiast część pierwszą pt. Zewnętrzna historia języka polskiego, traktującą o socjalno-politycznym i kulturalno-oświatowym podłożu rozwoju języka, część drugą, zatytułowaną Wewnętrzna historia języka polskiego, która poświęcona została charakterystyce polskiego systemu językowego oraz część trzecią, omawiającą dorobek polskiego językoznawstwa polonistycznego w ostatnim półwieczu, ze szczególnym uwzględnieniem kultury języka oraz zagadnień ortografii i ortofonii. Każdą z wyszczególnionych części zamyka podstawowa bibliografia, użyteczna zwłaszcza w dydaktycznym wykorzystaniu Zarysu.

Programowo autorka nie uwzględnia $w$ swoich rozważaniach socjolektów, czyli gwar i żargonów, koncentrując uwagę, jak jej wielki poprzednik, na języku ogólnym ${ }^{1}$. Czyni przy tym jednak pewne odstępstwo. W zgodzie $\mathrm{z}$ duchem czasu, wychodzi ze słusznego założenia, że język literatury „nie ma (dziś) większego wpływu na stan całości języka ogólnego", dlatego ani głównym obiektem obserwacji, ani podstawowym źródłem materiału nie czyni języka artystycznego, lecz potoczną wersję polszczyzny ogólnej, czego dowodzi przede wszystkim dobór materiału ilustrującego omawiane procesy i zjawiska językowe (s. 8). Poza tym znacznie więcej uwagi i miejsca niż Klemensiewicz, poświęca - jak to nazywa: specjalnym odmianom języka - zwłaszcza w rozdziale o kierunkach ich ewolucji (s. 93-120).

Nowatorskim pomysłem, chociaż zachęcającym do dyskusji, jest przyjęcie odmiennych cezur dla zewnętrznej i wewnętrznej historii języka. W pierwszym wypadku rozdział obejmuje lata 1945-2000, w drugim 1939-2000. To zróżnicowanie autorka tłumaczy przejściowym cha-

1 Z czego, nawiasem mówiąc, czyniono Klemensiewiczowi zarzut. 
rakterem i swoistością lat wojny, co znacząco warunkowało sytuację języka polskiego, a $\mathrm{z}$ kolei $\mathrm{w}$ niewielkim stopniu wpłynęło na toczące się swoim rytmem zmiany systemowe. Mniej przekonuje powołanie się na istnienie osobnej publikacji poświęconej temu okresowi.

I właśnie przywołana tu praca zbiorowa pt. Język polski czasu drugiej wojny światowej2 stanowi podstawę drugiej części uwag wstępnych, w której Autorka omawia trudną sytuację polszczyzny w latach 1939-1945, podkreślając zwłaszcza pogorszenie stanu języka ogólnego. Było ono wynikiem, z jednej strony, kurczenia się zasięgu języka polskiego na skutek deportacji i przesiedleń ludności posługującej się polszczyzną oraz wrogiego stosunku władz okupacyjnych, z drugiej zachwianiem się normy dawnego inteligenckiego języka na skutek mieszania się różnych warstw społecznych. W tym drugim procesie upatruje I.Bajerowa początków "demokratyzacji języka ogólnego" (s. 13)³.

Jednocześnie za najbardziej charakterystyczną właściwość języka polskiego czasu wojny uznaje zmiany w zasobie leksykalnym, zwłaszcza wzrost liczby zapożyczeń z języka niemieckiego, rosyjskiego i angielskiego oraz rodzimych neologizmów. Związane na ogół z realiami czasu wojny i okupacji zapożyczenia i rodzime nowotwory, choć zachowały się w słowniku współczesnej polszczyzny, to - podobnie jak przejęcia z okresu zaborów ${ }^{4}$ - mają dziś status historyzmów.

Z trzydziestu stron poświęconych Zewnętrznej historii języka polskiego lat 1945-2000 znacząca większość traktuje o występujących w tym czasie społeczno-politycznych i kulturalno-oświatowych uwarunkowaniach rozwoju i funkcjonowania polszczyzny.

I. Bajerowa za nadrzędny, wobec innych zjawisk społeczno-politycznych, uznaje wielki proces mieszania się i przewartościowywania układów społecznych. Po części jest on konsekwencją działań wojennych i okupacji (wielkie straty ludności, zwłaszcza wśród inteligencji; prowadzone na ogromną skalę akcje przesiedleńcze i samorzutne migracje w obrębie granic PRL, ale i emigracja zewnętrzna), po części

\footnotetext{
2 Pod red. I. Bajerowej, Warszawa 1996.

3 Rzecz jasna, widzianego $\mathrm{z}$ perspektywy końca $\mathrm{XX}$ wieku.

4 Por. m.in. H. Karaś, Rusycyzmy słownikowe w polszczyźnie okresu zaborớw, Warszawa 1996, B. Nowowiejski, Zapożyczenia leksykalne z języka niemieckiego w polszczyźnie XIX wieku, Białystok 1996.
} 
łączy się z ogólnymi zmianami cywilizacyjnymi (urbanizacja, uprzemysłowienie, „rewolucja kulturalna”), w jakimś fragmencie ma nacechowanie polityczne i ideologiczne (formowanie nowej inteligencji w drodze awansu społecznego, politycznego i kulturalnego klasy robotniczej i chłopstwa).

Nie bez wpływu na kształt powojennej polszczyzny pozostawały inne czynniki, zwłaszcza terytorialne. Duże znaczenie miało opuszczenie Kresów i zerwanie w konsekwencji wielowiekowych związków języka polskiego $\mathrm{z}$ białoruskim, ukraińskim, $\mathrm{w}$ mniejszym zakresie $\mathrm{z}$ jidysz. Przyznanie Polsce nowych obszarów łączyło się nie tylko z powstaniem nowych i silnych centrów polszczyzny, w tym nowego typu polszczyzny miejskiej, ale wymagało także pilnej akcji polonizacyjnej.

Zdaniem I. Bajerowej: „te wszystkie przesunięcia ludności (...) przyniosły $\mathrm{w}$ ostatecznym rezultacie (...) pozytywne a ważne dla rozwoju języka polskiego zjawisko: zwarcie się żywiołu polskiego, który w nowych granicach stał się bezwzględnie panujący i nie przedzielony wewnętrznymi innojęzycznymi terenami" (s. 23).

Omawiając czynniki kulturalno-oświatowe, Autorka wyróżnia w omawianym półwieczu, choć nieformalnie, kilka okresów: lata do roku 1970, dekadę Gierka, czas „Solidarności” i stanu wojennego, po których przychodzi przewrót roku 1989. W każdym z tych okresów zwraca uwagę na przesłanki, które $w$ największym zakresie oddziaływały na stan i rozwój języka. Za najistotniejsze dla losów polszczyzny w początkach PRL uznaje Autorka upowszechnianie kultury, któremu jednak towarzyszy jej podporządkowanie celom politycznym i ideologicznym. Przejawia się ono m.in. w laicyzacji kultury i oświaty (usunięcie religii ze szkół), wprowadzenie jako obowiązkowego języka rosyjskiego, funkcjonowanie cenzury, upaństwowienie kultury. W latach siedemdziesiątych następuje swoista liberalizacja polityki władz wobec kultury, większe otwarcie się na świat, rozwój mediów, zwłaszcza radia i telewizji. Po okresie strajków i stanu wojennego, kiedy życie kulturalne przybiera formy karykaturalne, a obie dominujące wersje: oficjalna i "podziemna” ostro ze sobą rywalizują, wraz z rokiem 1989 nadchodzi czas normalności, której sygnałem jest nie tylko komercjalizacja kultury, przejawiająca się m.in. w postaci wszechobecnej i silnie oddziałującej na język reklamy, ale przede wszystkim $\mathrm{w}$ pojawieniu 
się tendencji globalizacyjnych, i konkurujących ze standardami kultury masowej nowych "regionalnych" wzorców i zjawisk kulturowych.

W całej części wstępnej Autorka podkreśla szczególne znaczenie dla rozwoju rodzimego języka polskiej emigracji politycznej i ekonomicznej, reprezentującej falę okresu okupacji i stanu wojennego. Docenia też warunki, jakie dla rozwoju języka polskiego stworzono na obczyźnie.

Za bardzo znamienny należy uznać fakt, że szczególną rolę w rozwoju języka po drugiej wojnie światowej przypisuje I. Bajerowa nowemu czynnikowi sprawczemu, czyli - technice. Inna rzecz, że poświęca najwięcej miejsca i kładzie najsilniejszy nacisk na skutki oddziaływania radia i telewizji (s. 46). Tymczasem z dzisiejszego punktu widzenia może się wydawać, że zakres i rodzaj konsekwencji, jakie pociągnęły za sobą $\mathrm{w}$ sferze funkcjonowania języka oba te bardzo zasłużone dla rozwoju cywilizacji w XX wieku media, nie mogą równać się ze skutkami pojawienia się komputerów i internetu. Ponieważ jednak dziś trudno jeszcze o obiektywną tego ocenę, nasze opinie muszą pozostać $\mathrm{w}$ sferze prognozowania.

W tym kontekście za swoiste signum temporis uznać należy swoistą przecenę roli piśmiennictwa. Czynnik, który przez wieki w przemożny sposób wpływał na charakter i jakość polszczyzny, dostarczał językowego materiału, tworzył nowe modele słowotwórcze, kreował wzorce językowych zachowań, u schyłku XX wieku ustępuje pola technice.

W części zatytułowanej Wewnętrzna historia języka polskiego, mimo że Autorka dzieli ją na sześć rozdziałów, można wyodrębnić w zasadzie dwa kompleksy zagadnień. Pierwszy obejmuje charakterystykę systemową języka polskiego (fonologia z fonetyką, fleksja, słowotwórstwo, składnia i słownictwo $z$ frazeologią), drugi obrazuje zmiany i kierunki ewolucji odmian języka ogólnego.

Warto podkreślić, że przy omawianiu zmian systemowych I. Bajerowa wyróżnia dwie grupy procesów, mianowicie takie, których początki można już dostrzec $\mathrm{w}$ dobie nowopolskiej i takie, o których Klemensiewicz nie wspomina.

W części poświęconej zjawiskom fonetycznym za nazbyt kategoryczne trzeba uznać oceny dotyczące zaniku przedniojęzykowego $t$ i dźwięcznego $h$ oraz intonacji typu kresowego, które Autorka wiąże wyłącznie z rozproszeniem ludności z Kresów wschodnich. Wpraw- 
dzie, jak to wynika m.in. $\mathrm{z}$ moich obserwacji, wymowa typu kresowego jest $\mathrm{w}$ odwrocie $\mathrm{w}$ ośrodkach miejskich wschodniego pogranicza ${ }^{5}$, to jednak nie ulega wątpliwości, że w całym pasie pogranicza polsko-ruskiego wszystkie te zjawiska, o których nieobecności się przesądza, są ciągle żywotne i to nie tylko w języku osób w podeszłym wieku (czego dowodzi wymowa podpisanego pod tym tekstem).

Formy czasu zaprzeszłego, niewątpliwie $\mathrm{w}$ ogóle rzadkie $\mathrm{w}$ polszczyźnie 2 połowy XX wieku, zwłaszcza w jego ostatnim dwudziestoleciu, należy jednocześnie przypisywać niemal wyłącznie starszym użytkownikom polszczyzny. Warto też zauważyć, że formy czasownikowe na -ywam (wykonywam) ustępują nie tylko pola alternatywnemu modelowi na -uję (wykonuję), ale też na rzecz niepoprawnych kontaminacji typu wykonywuję! Nie wspomina Autorka ani słowem o sytuacji imiesłowów, a warto chyba podkreślić, że po wojnie obserwujemy dalszą redukcję zasobu form tego typu; na naszych oczach wychodzi $\mathrm{z}$ użycia imiesłów zaprzeszły, nie występuje zupełnie w języku mówionym, tylko wyjątkowo można go spotkać w tekstach pisanych!

Wypada zgodzić się z I. Bajerową, że na skutek braku, porównywalnego z obszernym i wnikliwym opracowaniem H. Jadackiej ${ }^{6}$, ujęcia słowotwórstwa doby nowopolskiej niełatwo skonfrontować procesy charakterystyczne dla drugiej połowy $X X$ wieku ze zjawiskami obecnymi w poprzedniej epoce rozwoju polszczyzny. Niemniej jednak udało się $\mathrm{w}$ Zarysie przedstawić najistotniejsze fakty $\mathrm{z}$ tego zakresu.

Szczególną rolę przypisuje Autorka procesowi internacjonalizacji, który nie tylko przenika całe polskie słowotwórstwo drugiej polowy $\mathrm{XX}$ wieku, ale stale się nasila. $\mathrm{W}$ jego wyniku pojawiły się na gruncie języka polskiego obce modele słowotwórcze, liczne zapożyczone formaty przedrostkowe i przyrostkowe oraz komponenty złożeń (wszechobecne $w$ terminologii naukowej). Bardzo widoczna jest też tendencja do kondensacji przejawiająca się głównie w ekspansji różnego typu złożeń i skrótowców oraz w procesach uniwerbizacji. Nawiasem mówiąc, zarówno skrótowce, jak i formacje zuniwerbizowane niegdyś uchodziły

5 Por. B. Nowowiejski, Język mieszkańców Białegostoku w końcu XX wieku, w: Biatystok $w$ 80-leciu, red. C. Kuklo, Białystok 2000, s. 211-222.

6 System stowotwórczy polszczyzny (1945-2000), Warszawa 2001. 
za swoiste wyznaczniki języka potocznego, dziś na skutek dynamicznej kolokwializacji różnych odmian języka ogólnego, zwłaszcza obecnych w mediach, utraciły chyba to nacechowanie.

Wymienionym procesom towarzyszy słabnięcie derywacji sufiksalnej, aczkolwiek da się zauważyć, przynajmniej okresowe, nasilanie się produktywności niektórych formantów, np. -arka tworzącego rzeczowniki (tu dalsze nowe przykłady: niszczarka, ładowarka (np. do telefonu komórkowego), nagrywarka, przegrywarka, wypalarka czy -owy bardzo produktywnego $\mathrm{w}$ tworzeniu przymiotników od różnego typu podstaw rzeczownikowych, w tym niemal zupełnie nie zaadaptowanych wyrazów obcego pochodzenia (por. cateringowy, dumpingowy, franchisingowy, rattingowy, snowboardowy, undergroundowy, windsurfingowy ${ }^{7}$ ). Uzupełniając spostrzeżenia I. Bajerowej, warto dodać, że sufiks -owy był już w tej roli bardzo aktywny w wieku XIX .

Trzeba też podkreślić, że stosunkowo łatwo tworzy się w polszczyźnie $X X$ wieku nie tylko hybrydy zbudowane $z$ cząstek rodzimych i obcych, ale także takie, w których występują wyłącznie elementy etymologicznie obce: antyfutbol, infostrada, bakterioland, sznapsgate, automotofanclub, automotohobby.

Istotne przeobrażenia zasobu leksykalnego polszczyzny $\mathrm{w}$ interesującym nas okresie wiążą się przede wszystkim z życiem wyrazów. I. Bajerowa podkreśla jednak, że przy stałym procesie obumierania słownictwa, zwłaszcza słownictwa dotyczącego desygnatów wychodzących z użycia, obserwujemy istotny przyrost nowych jednostek, których liczbę, na podstawie obserwacji T. Smółkowej i M. Szymczaka, ale i własnych doświadczeń, szacuje na dziesiątki tysięcy (s. 80). Warto jednak przypomnieć, że nie bierze się tu pod uwagę, zgodnie z przyjętym założeniem, słownictwa gwarowego i socjolektalnego. W innym wypadku liczba ta musiałaby być znacznie wyższa.

Za najsilniej oddziałujące na życie wyrazów uznaje Autorka uwarunkowania społeczno-polityczne i ideologiczne oraz rozwój techniki.

7 Por. B.Nowowiejski, Makaronizmy końca XX wieku, „Białostockie Archiwum Językowe” 2, 2002, s. 102.

8 Por. B. Nowowiejski, Zapożyczenia..., zwł. s. 225 (tu przykłady: amtshauptmanowy, asenterunkowy, bankocetlowy, erbpachtowy, forszpanowy, knapszaftowy, landszaftowy, landwerowy, liwerunkowy, rejchstagowy, szlachtuzowy, trejbhauzowy). 
Po 1989 do głosu dochodzą nowe czynniki, jak: reklama, rozwój i nasilone oddziaływanie mediów masowych, oraz - jak to bywało niemal w całej historii języka - mody i zwyczaje. To one decydują o chronologii wpływów obcych, początkowo głównie niemieckich, potem rosyjskich, wreszcie angielskich. Widoczną w ostatnich kilkunastu latach intensyfikację i zróżnicowanie wpływu języka angielskiego wiąże Autorka $\mathrm{z}$ procesem internacjonalizacji języków narodowych. Szczególnym jego przejawem jest wzrost, bezwzględny i w proporcji do przejęć formalnosemantycznych, liczby replik strukturalnych i semantycznych. Znamienne dla polszczyzny końca wieku jest też włączanie w obręb rodzimych tekstów oryginalnych wtrętów z języka angielskiego, swoiste makaronizowanie ${ }^{9}$.

Różne jest podłoże i przyczyny ekspansji wulgaryzmów w języku potocznym i artystycznym, w wypowiedziach polityków i kobiet. Tendencje globalizacyjne, słabnięcie zasady stosowności i agresywna emancypacja to tylko niektóre $\mathrm{z}$ nich ${ }^{10}$.

Na tle dość wyraźnych i nieraz istotnych dla stanu polszczyzny zmian na poziomie słowotwórczo-leksykalnym i frazeologicznym, zaskakują stosunkowo mało zauważalne zmiany w składni, a i one nie są tworem współczesnym, zaznaczyły swoją obecność we wcześniejszych epokach funkcjonowania polszczyzny.

Analizując zasadnicze kierunki przekształceń specjalnych odmian języka, Autorka bierze pod uwagę przede wszystkim zmiany wynikające z ich wzajemnych oddziaływań. Okazuje się, że najistotniejszym czynnikiem w przeobrażeniach języka artystycznego, medialno-urzędowego i religijnego odgrywa potocyzacja. Oczywiście język potoczny wpływa na te odmiany z różną siłą i zróżnicowane są przejawy tego oddziaływania. Dowodem nobilitacji potoczności w języku literatury jest głównie warstwa leksykalna, bogata w brutalizmy, wulgaryzmy, turpizmy i kolokwializmy oraz potoczne frazeologizmy, których liczna obecność prowadzi do „depoetyzacji” języka artystycznego (s. 101). Paradoksalnie, zupełnie odmienne zjawisko obserwujemy na gruncie języka

\footnotetext{
9 Por. B. Nowowiejski, Makaronizmy..., s. 93-112.

10 Por. K. Handke, Wulgaryzmy w języku Polek XX wieku, w: Polszczyzna dawna i wspótczesna, red. Cz. Łapicz, Torun 1994, s. 52.
} 
nauki, który unika banalizującej i upraszczającej kolokwializacji, za to szuka nowych form wyrazu nie tylko $w$ formalizacjach i symbolach, ale też $\mathrm{w}$ chwytach retorycznych i środkach stylistycznych.

W funkcjonowaniu języka religijnego, uznawanego od pewnego czasu za funkcjonalną odmianę języka literackiego ${ }^{11}$, poza zastąpieniem łaciny polszczyzną, najbardziej zauważalnym zjawiskiem jest jego uwspółcześnianie, które polega przede wszystkim na kolokwializacji. Mniej zwraca uwagę usuwanie słownikowych archaizmów i terminologizacja techniczna, a nawet urzędowa.

Za ważne i interesujące novum, zwłaszcza w świetle celnej uwagi, że "to media stanowią obecnie główny kanał informacyjny i na podstawie kształtu ich języka formują się potoczne sądy o właściwościach języka ogólnego" (s. 89), należy uznać wyodrębnienie w Zarysie języka medialnego, który po okresie funkcjonowania w postaci propagandowej nowomowy, stał się demokratyczną odmianą języka dotkniętą tymi samymi procesami, co inne odmiany. Obserwujemy tu nie tylko ekspansję potoczności, która - podobnie jak w wypadku języka religijnego - niejednokrotnie miesza się z patosem, ale też silną unifikację, która stopniowo zaciera tradycyjne różnice między polszczyzną $\mathrm{w}$ prasie, radiu i telewizji. Wypada zgodzić się z Autorką, że pewna część tekstów urzędowych dociera do odbiorcy za pośrednictwem mediów, jest chyba jednak pewną przesadą czynienie $z$ tego faktu argumentu przemawiającego za słusznością łączenia $w$ funkcjonalną jedność stylu urzędowego i języka mediów.

Zamykający książkę I. Bajerowej rozdział Praca nad językiem ogólnopolskim obejmuje dwa zagadnienia. Najpierw Autorka omawia w dużym skrócie (na dwunastu stronach) dorobek polskiego językoznawstwa polonistycznego, wyróżniając główne kierunki rozwoju badań (strukturalizm, gramatyka generatywna, pragmalingwistyka, socjolingwistyka, kognitywizm), przedstawiając synchroniczne i diachroniczne syntezy większych działów, od fonetyki i składni, przez semantykę i leksykologię, po historię języka i stylistykę językoznawczą.

11 Por. A. Wilkoń, Typologia odmian językowych wspótczesnej polszczyzny, Katowice 2000, s. 95. 
Osobne miejsce zajmują $\mathrm{w}$ tym wywodzie nowatorskie prace metodologiczne, wiele uwagi poświęca się wielkiemu dorobkowi polskiej leksykografii oraz edytorstwu tekstów, zwłaszcza zabytków staropolskich. Rozdział zamykają uwagi na temat opracowań bibliograficznych.

Problematykę kulturalnojęzykową rozpatruje I. Bajerowa w dwóch planach, teorii i praktycznej działalności. Podkreśla szczególne znaczenie dla rozwoju tej pierwszej strukturalizmu i walki z nowomową. Z kolei $\mathrm{w}$ upowszechnianiu poprawnej polszczyzny dużą rolę przypisuje działalności wydawniczej, szkolnej i akademickiej edukacji oraz instytucjonalnej (Ustawa o języku polskim, powołanie do życia Rady Języka Polskiego) i indywidualnej (wykłady, prelekcje, poradnictwo prasowe, radiowe i telewizyjne) opiece nad językiem.

Zgadzając się $\mathrm{w}$ pełni $\mathrm{z}$ oceną dorobku polskiej kultury języka w okresie powojennym, nie sposób jednak przejść obojętnie wobec, jak się wydaje, nazbyt optymistycznie brzmiącej oceny skutków tej działalności, zwłaszcza w zakresie postaw wobec języka i stopnia świadomości językowej Polaków. I. Bajerowa chyba nazbyt optymistycznie twierdzi że „dla Polaków język jest wartością, którą należy cenić i pielęgnować" (s. 144), dodaje też że "młodzież interesuje się stanem języka i chce władać pięknym i poprawnym" (s. 145). Nawet jeśli tak mówią wyniki ankiet i sondaży czy wypowiedzi niektórych uczniów i studentów, to praktyka dnia codziennego wskazuje niestety na coś zupełnie innego ${ }^{12}$.

Za dyskusyjną trzeba chyba uznać rolę mediów. Z jednej strony mają one niezwykłą szansę propagowania dobrych wzorców językowych, w czym nieraz biorą udział, z drugiej zdeterminowane ostrą rywalizacją $\mathrm{w}$ warunkach komercyjnego rynku medialnego nazbyt często "sprzedają" swe programowe treści w łatwo przystępnym i atrakcyjnym, czyli - potocznym, ekspresywnym i niechlujnym - językowym "opakowaniu".

Zatem postulat I. Bajerowej, by dobrych wzorców językowych dostarczały media trzeba chyba zaliczyć do kategorii pobożnych życzeń. Inaczej rzecz się ma z dobrą lekturą, która choć dostępna na rynku

12 Por. na ten temat uwagi K. Ożoga w książce Polszczyzna przełomu XX i XXI wieku. Wybrane zagadnienia, Rzeszów 2001, zwł. s. 184-189. 
księgarskim ma zbyt małe wzięcie, wypierana przez prymitywne "czytadła", internetowe "bryki" i ściągi.

$Z$ rozległego kręgu zagadnień kulturalnojęzykowych przedmiotem rozważań ostatniej części książki stały się ortografia i ortofonia, jako te działy, które - zdaniem Autorki - nastręczają użytkownikom polszczyzny szczególnych trudności i przeszły ostatnio znamienną ewolucję. $\mathrm{W}$ wymowie widać to zwłaszcza $\mathrm{w}$ obniżeniu normy, dla której podstawy nie stanowią już autorytety, lecz codzienna językowa komunikacja. Z kolei w zwyczajach pisownianych, zwłaszcza po roku 1989, obserwujemy niekorzystne zmiany będące wynikiem oddziaływania obcych wzorców graficznych dominujących w tekstach reklamowych i internecie.

Podsumowując swoje rozważania, I. Bajerowa za szczególnie istotne dla rozwoju polszczyzny lat 1939-2000 uznaje czynniki zewnętrzne, zwłaszcza proces upowszechnienia języka ogólnego, demokratyzację kultury i języka, coraz większy udział mediów w komunikacji społecznej oraz tendencje globalizacyjne.

Najważniejsza konkluzja sprowadza się jednak do kwestii periodyzacji najnowszych dziejów polszczyzny. I. Bajerowa dochodzi do wniosku, że rok 1939 zamyka dobę nowopolską i rozpoczyna nowy okres w historii polszczyzny - epokę "medialną". Autorka dzieli ją na trzy etapy: lata 1939-1960, 1960-1989 i 1989-2000. Po fazie przejściowej lat 1939-60 wyodrębnia wyraźnie zarysowaną "nową dobę historii języka polskiego", w której główną cezurę, swoisty „punkt graniczny” stanowi rok 1989, po którym następują zasadnicze zmiany warunków rozwoju języka polskiego.

Nie wątpię, że omawiana synteza najnowszych dziejów polszczyzny w znacznym stopniu zaspokoi potrzeby nie tylko uczniów i studentów, ale też zawodowych historyków języka. Sprzyja temu jasny i rzeczowy ton wykładu, wszechstronność ujęcia przedstawianych zagadnień, dyscyplina metodologiczna. Warto też podkreślić, że nie zapomina Autorka o prawie czytelnika do własnej oceny zjawisk, daje mu szansę na własną refleksję i indywidualną interpretację faktów. 